\title{
Clinical response to the long acting somatostatin analogue SMS 201-995 in a child with congenital microvillus atrophy
}

\author{
R T L COUPER, A BERZEN, G BERALL, AND P M SHERMAN \\ From the Division of Gastroenterology, Department of Pediatrics, Research Institute, The Hospital for Sick \\ Children, University of Toronto, Toronto, Canada
}

SUMMARY A 27 month old girl with congenital microvillus atrophy received two courses of SMS 201-995, a synthetic long acting analogue of native somatostatin, in an attempt to decrease profuse secretory diarrhoea. During the first trial at 13 months of age fluid and electrolytes administered by parenteral infusion were decreased as measured by water and faecal electrolyte losses. During the second trial of SMS 201-995 at 19 months fluid and electrolyte input were held constant for 14 days. Stool volume declined from $275 \mathrm{ml} / \mathrm{kg}$ to $161 \mathrm{ml} / \mathrm{kg}$. Reductions in output of stool electrolytes $\left(\mathrm{Na}^{+}\right.$, $\mathrm{K}^{+}, \mathrm{Cl}^{-}$) were accompanied by an increase in urine fluid output and increased excretion of urinary $\mathrm{Na}^{+}$. Subsequent administration of SMS 201-995 for a nine month period was not associated with adverse side effects or an impairment of growth velocity. These findings suggest that SMS 201-995 may be useful therapy in infants with high output diarrhoea as a result of congenital microvillus atrophy.

Congenital microvillus atrophy is a distinct clinical entity which presents with intractable watery diarrhoea in the first few days of life. ${ }^{1}$ Histology of small intestinal mucosa shows severe villus atrophy without crypt hyperplasia or an inflammatory infiltrate in the lamina propria. ${ }^{2}$ Transmission electron microscopy of small intestinal and rectal mucosa is diagnostic because microvilli on the apical plasma membrane are either very shortened and irregular, or completely absent. In addition, microvillus inclusions consisting of intracytoplasmic vacuoles lined with microvilli are contained within the cytosol of enterocytes. ${ }^{12}$

The longterm prognosis in affected infants is extemely poor as they are completely dependent on parenteral alimentation for nutritional support and maintenance of hydration. All attempts at oral feeding increase the volume of stool output. ${ }^{2}$ Each of the patients first reported, died during their first year of life. ${ }^{1-4}$ Despite attempts to modulate the diarrhoeal

Address for correspondence: P Sherman, MD, Room 1448, The Hospital for Sick Children, 555 University Avenue, Toronto, Ontario, Canada M5G 1 X8. Accepted for publication 28 November 1988. losses, all forms of pharmacological interventions used to date have not been successful. ${ }^{1-5}$

SMS 201-995 is a potent longacting analogue of native somatostatin. It is effective in the treatment of a variety of severe secretory diarrhoeal disorders. For example, SMS 201-995 has been used with success in adults with vasoactive intestinal peptide secreting tumours, ${ }^{6}$ high output ileostomy diarrhoea, ${ }^{7}$ diabetic diarrhoea, ${ }^{8}$ and cryptosporidiosis. ${ }^{9}$ In this report we describe the clinical response to SMS 201-995 in an infant with congenital microvillus atrophy.

\section{Case history}

A 27 month old girl first presented at three days of age with profuse watery diarrhoea, dehydration, and metabolic acidosis. The pregnancy was uncomplicated without evidence of polyhydramnios and birthweight was $2.3 \mathrm{~kg}$ at term gestation. Her parents were non-consanguinous.

A diagnosis of congenital microvillus atrophy was established by the electron microscopic appearance of duodenal and rectal mucosa. Pathognomonic 
intracytoplasmic brush border inclusions ${ }^{2}$ were present in surface epithelial cells of duodenal and rectal mucosa.

The diarrhoea and resulting fluid and electrolyte imbalances were controlled with the administration of parenteral fluids. All attempts at oral feeding resulted in high output watery diarrhoea, abdominal distension, weight loss, and metabolic acidosis. No known bacterial, viral or parasitic enteric pathogens were detected in the stools. While nil per os stool electrolytes were (in $\mathrm{mmol} / \mathrm{l}$ ): $\mathrm{Na}^{+} 100, \mathrm{~K}^{+} 29, \mathrm{Cl}^{-} 82$.

At 10 weeks of age she was discharged home on a parenteral nutrition programme. An episode of hyponatraemic dehydration (sodium $=122 \mathrm{mmol} / \mathrm{l}$ ) at four months of age required an upward adjustment of sodium and water in the parenteral alimentation solution. At eight months of age she was admitted with severe hypernatraemic dehydration $\left(\mathrm{Na}^{+} 154\right.$ $\mathrm{mmol} / \mathrm{l}, \mathrm{Cl}^{-} 124 \mathrm{mmol} / \mathrm{l}$ ) which was apparently related to an associated Staphylococcus aureus sepsis. Acute renal failure developed with a serum urea of 40 $\mathrm{mmol} / \mathrm{l}(\mathrm{N}=2.9-10 \mathrm{mmol} / \mathrm{l})$ and a serum creatinine of $369 \mu \mathrm{mol} / 1 \quad(\mathrm{~N}<44 \mu \mathrm{mol} / \mathrm{l})$. No diuretic response was obtained after intravenous fluid and diuretic challenge. Percutaneous renal biopsy showed histological changes that were consistent with acute tubular necrosis. Slow recovery of renal function occurred after 30 days of intermittent peritoneal dialysis. Throughout the admission stool losses, while nil per os, were between 70 and $100 \mathrm{ml} / \mathrm{kg} /$ day.

At 13 months of age, while still nil per os, daily fluid requirements had increased to $415 \mathrm{ml} / \mathrm{kg} /$ day. Daily requirement of sodium was $31.2 \mathrm{mmol} / \mathrm{kg}$ and of potassium, $8.3 \mathrm{mmol} / \mathrm{kg} / \mathrm{day}$. Fluid losses in the stools varied between 210 and $310 \mathrm{ml} / \mathrm{kg} /$ day.

\section{Methods}

MATERIALS

Baseline stool and urinary electrolyte losses were determined for one week before two separate trials of therapy. A synthetic long acting analogue of native somatostatin, SMS 201-995, was supplied to us by Sandoz Pharmaceuticals (Dorval, Quebec, Canada) in a concentration of $500 \mu \mathrm{g} / \mathrm{ml}$. Two separate courses of $100 \mu \mathrm{g}(0.2 \mathrm{ml})$ SMS 201-995 were administered by subcutaneous injection twice daily for 21 days and 14 days. During the first course at 13 months, parenteral fluid intake was adjusted daily depending on stool output, body weight and serum electrolytes. The second 14 day trial of SMS 201-995 was performed at 19 months using the same dose and route of administration. During the second course of therapy the volume, nutrient and electrolyte composition of the parenteral nutrition infusion were kept constant.
During baseline and trial periods body weight was determined twice daily. Volume and electrolyte composition of stool and urine were measured for 24 hour periods, once weekly after the insertion of a urinary catheter. Serum electrolytes and blood glucose were measured twice weekly. A complete blood count, serum calcium, phosphate, magnesium, urea, creatinine, total protein and albumin, and haemoglobin $\mathrm{A}_{1} \mathrm{C}$ were measured once weekly. Serum aldosterone and plasma renin activity were measured weekly, two to three hours after the morning dose of SMS 201-995.

Informed written parental consent was obtained after approval for the use of SMS 201-995 in this child was provided by the Health Protection Branch of Health and Welfare Canada.

\section{Results}

TRIAL 1

Stool output decreased from $210 \mathrm{ml} / \mathrm{kg} /$ day to $150 \mathrm{ml} /$ $\mathrm{kg} /$ day by day 8 . Supplemental sodium and potassium requirements decreased from $31.2 \mathrm{mmol} / \mathrm{kg} /$ day and $8.3 \mathrm{mmol} / \mathrm{kg} /$ day to $17.6 \mathrm{mmol} / \mathrm{kg} /$ day and $4.7 \mathrm{mmol} /$ $\mathrm{kg} /$ day, respectively, by day 10 . Exogenous fluid requirement decreased from $415 \mathrm{ml} / \mathrm{kg} /$ day to $232 \mathrm{ml} /$ $\mathrm{kg} /$ day by day 14 . A rebound towards baseline levels, however, was noted in all parameters between days 15 and 21 . Body weight increased by $0.33 \mathrm{~kg}$, from $5.76 \mathrm{~kg}$ to $6.07 \mathrm{~kg}$, during the period of SMS 201-995 administration.

We were unable to show a consistent effect on urinary sodium concentrations possibly because as stool and urinary losses diminished, fluid input was decreased accordingly. Plasma renin concentrations, however, decreased from a pretreatment level of $>76.8 \mathrm{ng} / \mathrm{l} / \mathrm{s}$ to $2.5 \mathrm{ng} / \mathrm{l} / \mathrm{s}$. In addition, serum aldosterone decreased from $15050 \mathrm{pmol} / \mathrm{l}$ to 1430 $\mathrm{pmol} / \mathrm{l}$ after SMS 201-995 therapy. Both findings provided indirect evidence that fluid and electrolyte homeostasis improved during therapy. A reduction in serum gastrin levels from $290 \mathrm{ng} / 1$ (normal $<90$ ) to $42 \mathrm{ng} / \mathrm{l}$ was also observed. Both glucose and $\mathrm{HbA}_{1} \mathrm{c}$ concentrations were unaffected.

After cessation of therapy parenteral fluid requirements increased to $355 \mathrm{ml} / \mathrm{kg} /$ day and stool losses increased to $270 \mathrm{ml} / \mathrm{kg} /$ day. A second trial of SMS 201-995 was, therefore, initiated at 19 months of age.

\section{TRIAL 2}

The effects of SMS 201-995 on the output stool and urine are summarised in the Figure. From a baseline stool output of $275 \mathrm{ml} / \mathrm{kg} /$ day a decline to $187 \mathrm{ml} / \mathrm{kg}$ / day was noted by day 3 of therapy. Stool volume was further decreased $(161 \mathrm{ml} / \mathrm{kg} /$ day $)$ by day 14 . Electrolyte composition of stools remained unchanged 


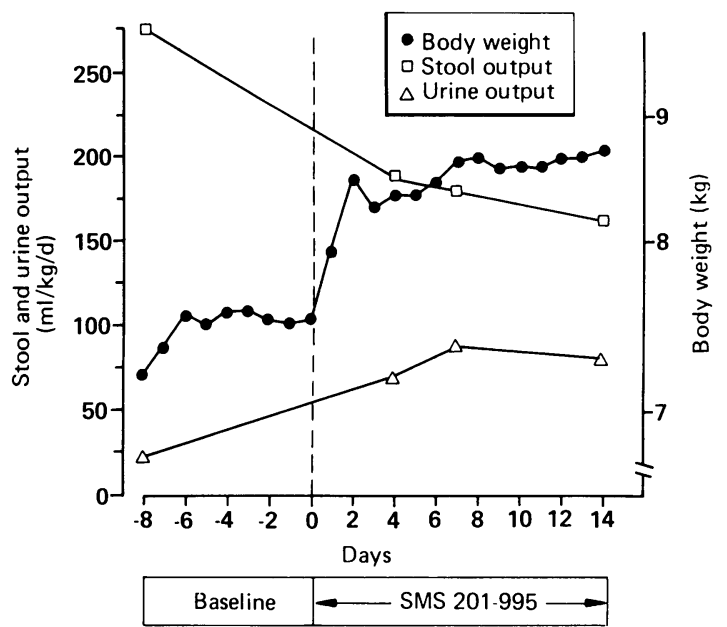

Figure Bodyweight $(\mathrm{kg})$ and stool and urine output $(\mathrm{ml} / \mathrm{kg} / \mathrm{d})$ during the one week before and during the 14 days of the second course of SMS 201-995. Intake of fluid and electrolytes were held constant over the entire 21 day study period.

throughout the trial (Table). Total stool losses of sodium and potassium decreased, however, in parallel with the reduction of total stool volume.

Daily urine output increased from $23.5 \mathrm{ml} / \mathrm{kg}$ before treatment to a maximum output of $87 \mathrm{ml} / \mathrm{kg}$ at day 7. Urinary electrolytes showed increasing concentrations of sodium and decreasing concentrations of potassium during the trial (Table). Further evidence of an improvement in fluid and electrolyte homeostasis during the second course of SMS

Table Parameters of electrolyte balance and hydration during 14 days of SMS 201-995. The amounts of parenteral fluid and electrolytes administered were held constant.

Trial of SMS 201-995

Baseline Day 4 Day $7 \quad$ Day 14

\begin{tabular}{llrrrc}
\hline Stool & & & & \\
$\quad$ Sodium conc & $(\mathrm{mmol} / \mathrm{l})$ & 106 & 116 & 112 & 123 \\
Potassium conc & $(\mathrm{mmol} / \mathrm{l})$ & 23 & 21 & 16 & 14 \\
Chloride conc & $(\mathrm{mmol} / \mathrm{l})$ & 93 & 103 & 105 & 107 \\
Sodium output & $(\mathrm{mmol} / \mathrm{kg} / \mathrm{d})$ & $29 \cdot 0$ & $21 \cdot 8$ & $22 \cdot 2$ & $19 \cdot 9$ \\
Potassium output & $(\mathrm{mmol} / \mathrm{kg} / \mathrm{d})$ & $6 \cdot 3$ & $3 \cdot 9$ & $2 \cdot 1$ & $2 \cdot 2$ \\
Chloride output & $(\mathrm{mmol} / \mathrm{kg} / \mathrm{d})$ & $25 \cdot 5$ & $19 \cdot 3$ & $19 \cdot 1$ & $17 \cdot 2$ \\
Urine & & & & & \\
Sodium conc & $(\mathrm{mmol} / \mathrm{l})$ & 6 & 17 & 19 & 3 \\
Potassium conc & $(\mathrm{mmol} / \mathrm{l})$ & 168 & 78 & 74 & 75 \\
Sodium output & $(\mathrm{mmol} / \mathrm{kg} / \mathrm{d})$ & $0 \cdot 1$ & $1 \cdot 2$ & $1 \cdot 7$ & $2 \cdot 8$ \\
Potassium output & $(\mathrm{mmol} / \mathrm{kg} / \mathrm{d})$ & $4 \cdot 0$ & $5 \cdot 5$ & $6 \cdot 5$ & $6 \cdot 3$ \\
Specific gravity & & $1 \cdot 019$ & - & $1 \cdot 007$ & $1 \cdot 008$ \\
Serum aldosterone* & $(\mathrm{pmol} / \mathrm{l})$ & 9830 & 4640 & 1860 & 4340 \\
Plasma renin $\dagger$ & $(\mathrm{ng} / \mathrm{l} / \mathrm{s})$ & $32 \cdot 40$ & - & $3 \cdot 61$ & $2 \cdot 86$ \\
\hline
\end{tabular}

${ }^{*}$ Normal $<940 \mathrm{pmol} / \mathrm{l} ;$ †Normal $<2 \cdot 80 \mathrm{ng} / \mathrm{l} / \mathrm{s}$.
201-995 therapy was provided by decreased concentrations of plasma renin, serum aldosterone, and urinary specific gravity (Table). In addition, after the first 48 hours of therapy, body weight increased by $0.82 \mathrm{~kg}$ without clinical evidence of fluid overload.

Subsequently, SMS 201-995 was continued for nine months in the outpatient clinic. During this interval body weight increased from well below the third percentile to the third percentile for age. Height velocity continued at a normal rate (for age) of $10 \cdot 2$ $\mathrm{cm} / \mathrm{yr}$ (actual increment $7.6 \mathrm{~cm}$ ). In addition the previous requirement for continuous, 24 hours per day, parenteral alimentation was eliminated and the child is now able to tolerate up to six hours per day without the administration of exogenous fluids.

No adverse effects related to the SMS 201-995 therapy were observed. In particular, glucose homeostasis was maintained as serum glucose and haemoglobin $\mathrm{A}_{1} \mathrm{C}$ concentrations remained normal.

\section{Discussion}

Two conceptual approaches have been used in the treatment of children with congenital microvillus atrophy. First, as there is severe villus atrophy and an underlying ultrastructural abnormality in enterocytes, treatment could, theoretically, be directed at promoting proliferation and differentiation of enterocytes. Therefore, putative trophic agents such as epidermal growth factors, ${ }^{5}$ pentagastrin, ${ }^{1}$ and corticosteroids $^{12}$ have been administered to infants with congenital microvillus atrophy. Although evidence for increased proliferation and differentiation of intestinal epithelial cells has been provided, ${ }^{5}$ none of these agents have resulted in an improvement of clinical symptoms.

The second approach to therapy recognises that the consequences of the high volume of stool output are dehydration, intravascular volume depletion and metabolic derangements. Therefore, there have also been attempts to diminish high output stool losses in patients with congenital microvillus atrophy by the use of antisecretory agents. For example, loperamide ${ }^{2}$ and native somatostatin ${ }^{3}$ have been used in previous therapeutic trials. Schmitz et al ${ }^{3}$ reported that native somatostatin reduced ileostomy fluid losses by $40 \%$ in one patient with congenital microvillus atrophy. Native somatostatin must be given by continuous intravenous infusion, however, because of its short duration of action. Therefore, it is impractical for longterm management.

In this open trial of SMS 201-995 administration to a child with congenital microvillus atrophy the daily stool output of water and electrolytes were markedly reduced. The decrease in stool output was accompanied by an increase in urine output, decreased 
specific gravity of the urine, increased natriuresis, decreased concentrations of serum aldosterone and a decline in plasma renin. These metabolic changes, which occurred in the second course of therapy during a period in which intake of fluids and electrolytes were kept constant, suggest a clinically relevant antisecretory response.

Previous case reports suggest that SMS 201-995 is also effective as therapy in other causes of high output secretory diarrhoea in patients in the pediatric age group. These include patients with vasoactive intestinal peptide (VIP)-secreting tumours, ${ }^{11}$ pancreatic hyperplasia with high circulating VIP concentrations, ${ }^{11}$ high output ileostomy diarrhoea, ${ }^{12}$ and idiopathic secretory diarrhoea..$^{1.3}$ The use of two temporally separate courses of therapy, however, as evidence to further support a beneficial response of SMS 201-995, was not documented in these previous reports. In addition, supportive evidence for an associated improvement in fluid homeostasis was not provided. ${ }^{11-1.3}$

The precise mechanism by which the long acting analogue of somatostatin exerts its beneficial effect in cases of secretory diarrhoea is uncertain. Santangelo et $a l^{10}$ reported a reversal from the net secretion of ions and water to net absorption in the jejunum after SMS 201-995 therapy. In contrast, Dueno et al ${ }^{14}$ observed no effect on ion and water absorption after infusion of SMS 201-995 into an isolated perfused segment of human jejunum. They found that intestinal transit time was increased. In addition, recovery of fluid decreased from the intestine proximal to the perfused segment; a finding which suggests that output of either pancreaticobiliary or gastric fluid was inhibited. SMS 201-995 inhibits gastric acid secretion in meal stimulated volunteers,${ }^{15}$ mediated by direct inhibition of gastrin release. A possible effect on the suppression of gastric secretion in our patient was demonstrated by a reduction in serum gastrin concentrations.

Preliminary evidence suggests that administration of SMS 201-995 has minimal adverse effects. ${ }^{16}$ For example, adults have received up to $600 \mu \mathrm{g} /$ day of SMS 201-995 without apparent adverse effect. ${ }^{17}$ Smith et al ${ }^{11}$ administered doses as high as $2000 \mu \mathrm{g} /$ day to an infant without side effects. Theoretically, glucose homeostasis could be altered by a direct suppression of insulin release. ${ }^{18}$ This has, however, not been reported as problematic.

In conclusion, we provide evidence to suggest that SMS 201-995 is associated with a reduction in the high output, watery diarrhoea of congenital microvillus atrophy. The somatostatin analogue facilitated maintenance of both fluid and electrolyte homeostasis and it also promoted increased weight velocity. Although its mode of action remains unknown, SMS 201-995 could prove useful in the treatment of other infants who are affected by this intractable enteropathy.

PS is the recipient of a Career Scientist Award from the Ontario Ministry of Health.

\section{References}

1 Davidson GP, Cutz E, Hamilton JR, Gall DG. Familial enteropathy: a syndrome of protracted diarrhea from birth, failure to thrive, and hypoplastic villus atrophy. Gastroenterology 1978; 75: 783-90.

2 Phillips AD, Jenkins P, Raafat F, Walker-Smith JA. Congenital microvillus atrophy: specific diagnostic features. Arch Dis Child 1985; 60: 135-40.

3 Schmitz J, Ginies JL, Arnaud-Battandier F, et al. Congenital microvillus atrophy, a rare cause of neonatal intractable diarrhoca [Abstract]. Pediatr Res 1982; 16: 1041.

4 Goutet JM, Boccon-Gibod L, Chatelet F, et al. Congenital and familial protracted diarrhoea with enterocyte brush border abnormalities [Abstract]. Pediatr Res 1982: 16: 1046.

5 Drumm B, Cutz E, Tomkins BK, et al. Urogastrone/ epidermal growth factor in treatment of congenital microvillus atrophy. Lancet 1988; i: 111-2.

6 Ruskone A, Rene E, Chayvialle JA, et al. Effect of somatostatin on diarrhea and on small intestinal water and clectrolyte transport in a patient with pancreatic cholera. Dig Dis Sci 1982; 27: 459-66.

7 Williams NS, Cooper JC, Axon AT, King RF, Barber $M$. Use of a long-acting somatostatin analogue in controlling life threatening ileostomy diarrhoea. Br Med J 1984; 289: 1027-8.

8 Dudl JR, Anderson DS, Forsythe AB, Ziegler MG, O'Dorisio TM. Treatment of diabetic diarrhea and orthostatic hypotension with somatostatin analogue SMS 201-995. Am J Med 1987; 83: 584-8.

9 Rene E, Regnier B, Laine MJ, Bonfils S. Somatostatin and cryptosporidial diarrhea during AIDS [Abstract]. Can J Physiol Pharmacol 1986; 64: 70.

10 Santangelo WC, Strickland AJ, Ducore JM, Krejs GJ. Long-term treatment of a child with pancreatic cholera syndrome with somatostatin analogue (SMS 201-995) [Abstract]. Can J Physiol Pharmacol 1986; 64: 66-7.

11 Smith SS, Shulman DI, O'Dorisio TM, et al. Watery diarrhea, hypokalemia, achlorhydria syndrome in an infant: effect of the long-acting somatostatin analogue SMS 201-995 on the disease and linear growth. $J$ Pediatr Gastroenterol Nutr 1987; 6: 710-6.

12 Ohlbaum Ph, Galperine RI, Demarquez JL, Vergnes P, Martin $\mathrm{Cl}$. Use of long-acting somatostatin analogue (SMS 201-995) in controlling a significant ileal output in a 5-year-old child. J Pediatr Gastroenterol Nutr 1987; 6: 466-70.

13 Jaros W, Biller J, Greer S, O'Dorisio T, Grand R. Successful treatment of idiopathic secretory diarrhea of infancy with the somatostatin analogue SMS 201-995. Gastroenterology 1988; 94: 189-93.

14 Dueno MI, Bai JC, Santangelo WC, Krejs GJ. Effect of somatostatin analog on water and electrolyte transport 
and transit in human small bowel. Dig Dis Sci 1987; 32: $1092-6$.

15 Olsen JA, Loud FB, Christiansen J. Inhibition of meal stimulated gastric acid secretion by an octapeptide somatostatin analogue SMS 201-995. Gut 1987; 28: 464-7.

16 Bloom SR, Polak JM. Somatostatin. Br Med J 1987; 295: 288-90.
17 Koelz A, Kraenzlin M, Gyr K, et al. Escape of the response to a long-acting somatostatin analogue (SMS 201-995) in patients with VIPOMA. Gastroenterology 1987; 92: 527-31.

18 O'Shaughnessy DJ, Long RG, Adrian TE, et al. Somatostatin 14 modulates postprandial glucose levels and release of gastrointestinal and pancreatic hormones. Digestion 1985; 31: 234-42. 